\title{
Reconsidering Islam in a South Asian Context
}

\author{
M. Reza Pirbhai \\ Leiden \& Boston: Brill, 2009. 370 pages.
}

This is an ambitious book, as M. Reza Pirbhai attempts to lift our understanding of Islam in South Asia, or indeed of Islam anywhere, both out of the essentializing straitjacket in which western Orientalist scholarship has placed it and out of a similar straitjacket in which many modern Muslims, often influenced by western scholarship, have also placed it. He is concerned to demonstrate that what he calls "doctrinal Islam" is

multidisciplinary and variable within disciplines. Theology includes concepts of immanent monism, transcendental monism, monotheism and absolute transcendentalism. Jurisprudence is rooted in four Sunni and two Shi'a schools, most accepting concepts of independent reasoning and consensus, some extending to notions of public utility, equity and the virtual inclusion of customary law as an additional source of the shari 'a. Mysticism ranges from concepts included in theology and jurisprudence to the addition of anti-nomian and latitudinarian doctrines.... (pp. 337-38)

The rich possibilities of the Islamic tradition are set before us - indeed, the potential for there to be many "Islams." In making sense of these possibilities, he brings forward two particular worldviews: the "Sober Path" and the "Intoxicated Way." The former divides the world into "Muslim" and "non-Muslim" and has its distinctive forms of hospitality and hostility to the resources it finds in any locality. The latter also contains a range of approaches, some intersecting with the sober path and others leading on to antinomian or latitudinarian ground. What is crucial, he insists, is that all remain equally valid expressions of doctrinal Islam, provided that no value judgment is made about what is orthodox Islam.

Pirbhai begins his book by establishing the Islamic tradition's rich doctrinal possibilities. He then goes on to examine the worlds of Mughal emperors Akbar and Awrangzib. The former he brands the quintessentially "Intoxicated Muslim," and the latter the "Sober Muslim." Chapter 3 examines the doctrinal changes taking place in the Sober Path during the eighteenth and nineteenth centuries, which were led by the Wali Allahi school. He demonstrates, quite rightly, that these have relatively little to do with the British presence and must be seen as "part of a far broader, pre-colonial attempt (extending across the Muslim world) to activate the doctrine of ijti- 
had (independent reasoning) to codify Islamic law by explicitly negating all doctrinal legitimisation of local complexes of thought and social customs ( $\mathrm{p}$. 13)." Chapter 4 shows how the British undermining of the traditional madrasa system in the nineteenth century created the circumstances that led to the growing dominance of the Sober Path among the Muslim elite. This said, it is also suggested from a study of Punjabi folk literature that this path's influence was increasingly being felt in the subaltern world.

Chapter 5 examines the works of Sayyid Ahmad Khan, Muhammad Iqbal, and Mirza Ghulam Ahmad of Qadian, showing that far from objectifying Islam through a western lens, they used longstanding doctrinal mechanisms to assimilate or reject aspects of European thought. In doing so, while their hospitality to western ideas represented a continuation of the Intoxicated Way, their insistence on ijtihad, legalism, and transcendentalism represented the Sober Path's dominance in their intellectual world. The final chapter considers the significance of this development in influencing Muslim ideas of community and nation. Pirbhai argues that both the new Intoxicated Way and the new Sober Path "played a pivotal role, along with colonial assumptions, institutions and pressures, in pushing the rise of 'communalism,' or religiously conditioned political identities" (p. 14).

This book offers a way to grasp the Subcontinent's Islamic history over the past four centuries. In doing so, the author draws upon both the field's considerable secondary literature and his own readings in primary sources in Arabic, Persian, and Urdu. He is in harmony with the concerns of contemporary scholars in wanting to remove the weight of Orientalist scholarship, as well as with those of the so-called Muslim orthodox, from our understanding - no easy task, as he demonstrates. There is no great originality in what he has to say, for instance, about the Sober Path's rise to dominance in the nineteenth and twentieth centuries, or in the contributions of the new Intoxicated Way and the new Sober Path, along with other factors, to the rise of a Muslim political identity in South Asian politics. What is new and valuable is to have these great processes of religious change, as well as their political implications, set out on a broad canvas.

Nevertheless, there are elements that sap confidence in the author's scholarship. For example: the name of the distinguished American historian of South Asian Islam, Barbara Metcalf, is misspelled throughout the book; there was no al-Sindhi family teaching Abd al-Wahhab and Wali Allah in Arabia, but rather a Muhammad Haya al Sindhi (p. 151); there were no such people as the Jawahar Brothers, but rather the 'Ali Brothers (p. 319); and it is unlikely that "innumerable peasants" peddled Urdu- 
language religious tracts (p. 26). There is also a certain looseness of thought: the "Muslim capitalist classes" are referred to on several occasions, but we are not told who they were; and there is the quite unwarranted assumption that the development of the capacity to "objectify" Islam in the nineteenth and twentieth centuries would prevent Muslims from drawing in different ways upon their rich doctrinal heritage. In places the prose is dense, the sentences too long, the language too abstract, and the meaning hard to discern. This book will definitely challenge the student, but established scholars will also benefit from it as well.

Francis Robinson

Professor of the History of South Asia, Department of History

Royal Holloway, University of London Sultan of Oman Fellow, Oxford Centre for Islamic Studies 